\title{
PENINGKATAN HIGH-SENSITIVE CARDIAC TROPONIN (HS- CTN) SETELAH LATIHAN INTENSITAS TINGGI YANG INTENSIF
}

\author{
Indira Vidiari J ${ }^{1}$, Nila Wahyuni ${ }^{2}$, I Putu Adiartha Griadhi ${ }^{3}$ \\ ${ }^{1}$ Department of Physiotherapy Medical Faculty Udayana University \\ 2, 3 Department of Physiology Medical Faculty Udayana University \\ Email : indiravidiarifk@unud.ac.id ; indiravidiari@gmail.com
}

\begin{abstract}
ABSTRAK
Peran olahraga sebagai strategi untuk pencegahan, manajemen dan terapi pada penyakit kardiovaskular telah dapat dijelaskan dengan baik, namun pada beberapa penelitian mengatakan bahwa terjadi peningkatan biomarker pada kerusakan jantung atau cardiac Troponin (cTn) setelah latihan dengan intensitas tinggi yang intensif pada individu yang sehat. Beberapa penelitian menunjukkan peningkatan troponin jantung yang signifikan setelah berbagai jenis olahraga. Meta-analisis terbaru, menunjukkan peningkatan high sentivity cardiac troponin (hs-cTn) pada sekitar $83 \%$ individu setelah latihan yang lama dan intensif. Patofisiologi peningkatan hs-cTn saat ini belum dapat dipahami dengan baik. Beberapa hipotesis telah diajukan, seperti kebocoran transmembran dari cytoplasmic free cTnT dan cTnI atau penurunan clearance troponin dari plasma, keduanya disebabkan oleh kelebihan muatan radikal bebas, peregangan miokardia, peningkatan suhu inti, atau perubahan dari $\mathrm{pH}$. Penelitian lebih lanjut diperlukan dengan studi prospektif yang sepenuhnya untuk mengevaluasi patofisiologi yang mendasari peningkatan high sentivity cardiac troponin (hs-cTn) adalah strategi yang efektif untuk mencegah atau membatasi cedera jantung, serta olahraga yang aman bagi jantung.
\end{abstract}

Kata kunci : cardiac Troponin (cTn), high sentivity cardiac troponin (hs-cTn), latihan intensitas tinggi intensif

\section{INCREASED HIGH-SENSITIVE CARDIAC TROPONIN (HS- CTN) AFTER HIGH INTENSIVE INTENSITY TRAINING}

\begin{abstract}
The role of exercise as a strategy for prevention, management and therapy in cardiovascular disease has been well described, but in some studies, it has been suggested that there is an increase in biomarkers in cardiac damage or cardiac troponin (cTn) after intensive, high-intensity exercise in healthy individuals. Several studies have shown significant increases in cardiac troponins after different types of
\end{abstract}


exercise. The latest meta-analysis, showing that high-sensitivity cardiac troponin (hscTn) increases in about $83 \%$ of individuals after long and intensive exercise. The current pathophysiology of hs-cTn is not well understood. Several hypotheses have been proposed, such as transmembrane leakage from cytoplasmic free cTnT and cTnI or decreased troponin clearance from plasma, both caused by overloading of free radicals, myocardial stretching, elevated core temperature, or alteration of $\mathrm{pH}$. Further research is needed with a full prospective study to evaluate the underlying pathophysiology of enhancing high sentivity cardiac troponin (hs-cTn) is an effective strategy for preventing or limiting cardiac injury and sport exercise safe for heart.

Keywords: cardiac Troponin (cTn), high sensitivity cardiac troponin (hs-cTn), high intensity intensive exercise

\section{Pendahuluan}

Troponin adalah suatu kompleks protein yang ditemukan pada seluruh filamen tipis otot bergaris atau aktin. Troponin dan tropomiosin berfungsi mengatur sensitivitas kalsium terhadap alat kontraktil aktomiosin. Perbedaan antara Troponin pada otot bergaris dan otot jantung terdapat pada susunan asam aminonya dan peningkatan antibodi terhadap epitop spesifik. Troponin terdiri dari 3 subunit, yaitu Troponin C, Troponin I, dan Troponin $\mathrm{T}^{1,2}$. Cardiac Troponin (cTn) yang terdiri dari cardiac Troponin $\mathrm{T}$ (cTnT) dan cardiac Troponin I (cTnI), menjadi biomarker pilihan untuk diagnosis Infark Miokard Akut (IMA), mengungguli biomarker Creatin Kinase Myocardial Band (CK-MB). Peningkatan cardiac Troponin $\mathrm{T}$ (cTnT) dan cardiac Troponin I (cTnI) merupakan biomarker yang baik dalam sirkulasi sebagai indikasi adanya nekrosis miokard ${ }^{2,3,4}$.

Peran olahraga sebagai strategi untuk pencegahan, manajemen dan terapi pada penyakit kardiovaskular telah dapat dijelaskan dengan baik, namun pada beberapa penelitian mengatakan bahwa terjadi peningkatan biomarker pada kerusakan jantung atau cardiac Troponin (cTn) setelah latihan dengan intensitas tinggi yang intensif pada individu yang sehat. Produksi cTn terjadi akibat dari gangguan pada alat kontraktil setelah cedera miokard iskemik ${ }^{5,6}$.

Artikel ini bertujuan untuk menyajikan serangkaian artikel penelitian berbasis bukti yang membahas tentang cardiac Troponin (cTn) sebagai biomarker pada kerusakan jantung dan hubungan antara latihan dengan cardiac Troponin (cTn).

\section{Metode \\ Review Article}

\section{Cardiac Troponin (cTn) sebagai Biomarker Kerusakan Jantung}

Kompleks troponintropomyosin mengatur kontraksi otot bergaris dan terdiri dari tiga subunit (troponin $\mathrm{C}$, troponin $\mathrm{T}$, dan troponin I). Troponin $\mathrm{C}$ adalah protein yang mengikat ion kalsium. Troponin $\mathrm{T}$ adalah protein yang mengikat tropomiosin, sehingga menghasilkan kompleks troponin-tropomiosin pada aktin. Troponin I adalah protein yang berikatan dengan aktin dan 
menurunkan afinitas troponin $\mathrm{C}$ untuk kalsium, sehingga menghambat interaksi aktin-myosin. Troponin $\mathrm{T}$ dan troponin I terdapat pada otot jantung maupun skeletal, tetapi keduanya dikodekan oleh gen yang berbeda dalam dua jenis otot tersebut, menghasilkan protein yang berbeda secara imunologi. Tes pemeriksaan yang didasarkan pada antibodi afinitas tinggi dan spesifik untuk cTnT dan cTnI. Urutan asam amino troponin $\mathrm{C}$ otot jantung dan troponin $\mathrm{C}$ otot bergaris adalah identik, belum ada tes yang dikembangkan untuk komponen troponin C. Mayoritas troponin jantung (cTn) terikat pada miofilamen, dan sisanya bebas dalam sitosol sebanyak 3\%-8\% dari jumlah total. Troponin akan dilepaskan dari cytoplasmic pool apabila ada gangguan pada membran sarcolemmal dari cardiomyocyte, kemudian diikuti oleh pelepasan yang lebih berkepanjangan akibat kerusakan miofilamen. Kadar cTnT mulai meningkat pada sirkulasi darah dalam rentang waktu tiga sampai empat jam setelah onset cedera miokard dan tetap meningkat selama 10-14 hari $^{7}$.

Peran troponin jantung sebagai biomarker diagnostik cedera miokardial dalam konteks Sindrom Koroner Akut (SKA) sudah terbukti. Sejak tes generasi pertama, tes high sentivity cardiac troponin (hs-cTn) pada generasi ke-5 telah dikembangkan, dan sekarang digunakan secara luas ${ }^{8}$. Uji generasi pertama untuk cTnT menggunakan cTnT sapi dan menunjukkan pengikatan non-spesifik untuk troponin otot bergaris pada manusia, tetapi masalah ini diatasi dengan penyempurnaan antibodi deteksi pada uji generasi kedua dengan cTnT manusia rekombinan. Uji generasi ketiga untuk standardisasi. Uji cTnT generasi keempat menggunakan Fragment Antigen-Binding (FAB) dari dua antibodi monoklonal cTnTspesifik pada tikus dalam format sandwich. Deteksi cTnT didasarkan pada electrochemiluminescence

menggunakan kompleks Tris (bipyridyl)-ruthenium(II) sebagai label. Uji cTnT generasi keempat memiliki batas deteksi atau Limit of Detection (LoD) 0,01 ng/mL, persentil ke-99 cut off point $0,01 \mathrm{ng} / \mathrm{mL}$, dan koefisien variasi atau Coefficient of Variation (CV) 10\% 0,03 ng/mL. Uji cTnT generasi keempat dianggap sebagai uji standar untuk diagnosis Infark Miokard Akut (IMA). Peningkatan cTn dalam darah melebihi persentil ke-99 dari referensi normal populasi, pedoman menunjukkan bahwa CV dari uji cTn yang ideal digunakan adalah $\leq 10 \%$ pada konsentrasi persentil ke-99, maka jelas, uji cTnT generasi keempat tidak memiliki ketepatan yang memadai. Uji high sentivity cardiac troponin (hscTn) merupakan modifikasi dari uji cTnT generasi keempat ${ }^{7}$.

Sindrom Koroner Akut (ACS) adalah keadaan darurat kardiovaskular yang mengancam jiwa. Diagnosis yang akurat dan stratifikasi risiko sangat penting karena manajemen terapeutik langsung pada pasien dikaitkan dengan prognosis perbaikan pasien yang signifikan. Troponin jantung telah menjadi komponen penting dari definisi infark miokard dan sangat diperlukan untuk deteksi dini, meskipun generasi saat ini tes high sentivity cardiac troponin (hs-cTn) 
tidak cocok dalam sensitivitasnya untuk mendeteksi kerusakan miokard, peningkatan hs-cTn dapat terjadi pada gangguan kardiovaskular akut atau kronis lainnya seperti gagal jantung, emboli paru, aritmia, atau gagal ginjal 9 .

\section{Hubungan antara Latihan dengan Cardiac Troponin (cTn).}

Beberapa penelitian menunjukkan peningkatan troponin jantung yang signifikan setelah berbagai jenis olahraga. Dalam metaanalisis terbaru, menunjukkan bahwa high sentivity cardiac troponin (hscTn) meningkat di atas persentil ke-99 pada sekitar $83 \%$ individu setelah latihan yang lama dan intensif. Patofisiologi peningkatan hs-cTn saat ini belum dapat dipahami dengan baik. Beberapa hipotesis telah diajukan, seperti kebocoran transmembran dari cytoplasmic free cTnT dan cTnI atau penurunan clearance troponin dari plasma, keduanya disebabkan oleh kelebihan muatan radikal bebas, peregangan miokard, peningkatan suhu inti, atau perubahan dari $\mathrm{pH}^{10}$.

Sebuah systematic review oleh Vilela et al. tahun 2014 dilakukan untuk mempelajari pola pelepasan high sentivity cardiac troponin (hs-cTn) setelah olahraga lari (pencarian dilakukan di PubMed, ISI Web of Knowledge dan Scopus databases). Sepuluh laporan telah diidentifikasi memenuhi kriteria yang ditentukan sebelumnya, terdapat delapan laporan menggunakan high sentivity cardiac troponin $T$ (hs-cTnT) dan dua laporan menggunakan high sentivity cardiac troponin I (hs-cTnI)). Sumber data diterbitkan antara tahun 2009 dan
2013, yang berjumlah total 479 peserta yang diteliti. Delapan laporan memberikan data yang membandingkan kadar troponin pasca olahraga lari dengan nilai referensi persentil ke-99. Sebanyak 296 peserta, dari 424, menunjukkan nilai high sentivity cardiac troponin (hs-cTn) pasca olahraga lari lebih tinggi dari nilai referensi persentil ke-99 $(69,8 \%)$. Kesimpulannya, penelitian ini menunjukkan bahwa terdapat peningkatan nilai high sentivity cardiac troponin (hs-cTn) pasca olahraga lari intensitas tinggi terlihat pada lebih dari dua pertiga pelari. Pelepasan troponin ini merupakan fenomena yang tidak diketahui sepenuhnya. Efek olahraga lari dengan intensitas tinggi pada kesehatan jangka panjang juga tidak diketahui dengan pasti ${ }^{11}$.

Sebuah penelitian oleh DeFina et al. pada tahun 2016 dikatakan bahwa ada hubungan terbalik antara Cardiorespiratory Fitness (CRF) dengan hs-cTnT dalam kelompok pria dan wanita yang umumnya sehat. Tingkat CRF yang lebih tinggi dikaitkan dengan tingkat hs-cTnT yang lebih rendah dan kemungkinan CRF lebih rendah memiliki tingkat peningkatan hs-cTnT yang signifikan yaitu $14 \mathrm{ng} / \mathrm{L}$ atau lebih besar. Hubungan terbalik tetap signifikan setelah penyesuaian untuk usia dan faktor risiko jantung tradisional. Penelitian ini merupakan studi pertama yang melihat hubungan antara CRF terukur dan hs-cTnT dan menunjukkan bahwa CRF rendah dapat dikaitkan dengan cedera miokardial kronis tingkat rendah. Penelitian lebih lanjut diperlukan dengan studi prospektif yang sepenuhnya untuk mengevaluasi 
patofisiologi yang mendasari peningkatkan CRF adalah strategi yang efektif untuk mencegah atau membatasi cedera jantung subklinis kronis ${ }^{12}$.

Sebuah laporan kasus oleh
Baird et al. pada tahun 2017
dikemukakan bahwa ketersediaan
dikemukakan bahwa ketersediaan energi rendah mungkin terkait dengan peningkatan cTnI setelah latihan anaerobik. Peningkatan kadar cTnI secara klinis kemungkinan disebabkan oleh mekanisme patologis atau respons fisiologis sementara dan di dalam latihan ketahanan, atau respon pada individu tertentu. Defisit kilokalori pada kasus ini tidak dapat ditentukan secara akurat, namun, data lain yang dikumpulkan mendukung adanya defisit energi. Penelitian selanjutnya harus menentukan keseimbangan energi menggunakan metode yang lebih akurat misalnya, akselerometer dan analisis diet yang lebih terkontrol. Biomarker lain dari fungsi jantung, misalnya, Peptida Natriuretik tipe B (BNP) atau N-Terminal pro-BNP dan ekokardiografi yang dikumpulkan setelah olahraga akan membantu dalam penentuan diagnosis, hal ini akan diperlukan untuk menguji interaksi antara latihan intensitas tinggi dan ketersediaan energi rendah pada wanita muda yang aktif di mana defisit kalori mungkin terjadi, jika hubungan antara defisit energi dan latihan intensitas tinggi dapat diidentifikasi ${ }^{13}$. Sebuah penelitian eksperimental oleh Tian et al. pada tahun 2012, yang membandingkan high sentivity cardiac troponin (hscTn) pasca olahraga lari treadmill yang berkepanjangan, disimpulkan bahwa daya tahan berlari selama 90 menit dilakukan pada intensitas relatif yang sama menyebabkan tingkat hscTnT yang lebih tinggi pada remaja dibandingkan dengan trainingmatched pelari. Disimpulkan bahwa besarnya nilai peningkatan kadar cTnT yang dipicu oleh latihan, dapat dipengaruhi oleh usia dan / atau status kedewasaan seseorang. Meskipun respon puncak hs-cTnT kemungkinan dipengaruhi oleh usia dan / atau kematangan, namun kinetika pelepasan hs-cTnT dengan latihan yang berkepanjangan sama pada pelari dewasa dan remaja ${ }^{14}$.

Level troponin $\mathrm{T}$ terdeteksi pada mayoritas peserta setelah pertandingan lari $5 \mathrm{~km}$ dan level memuncak setelah sekitar 4 jam. Dinamika Troponin $\mathrm{T}$ serum pada peserta yang sehat mengikuti jarak lari yang relatif singkat sejauh $5 \mathrm{~km}$ sejauh pengetahuan belum pernah dinilai sebelumnya. Data dapat membantu ketika peningkatan kadar serum Troponin $\mathrm{T}$ dievaluasi secara klinis setelah olahraga sehingga dapat dibedakan dari kemungkinan penyebab lain seperti miokarditis atau trauma. Tiga sampel dalam penelitian memiliki Troponin $\mathrm{T}$ yang melebihi tingkat referensi klinik cedera miokard. Peningkatan sementara dalam serum Troponin $\mathrm{T}$ kemungkinan disebabkan oleh nekrosis sel miokard atau dapat juga Troponin $\mathrm{T}$ hanya dilepaskan oleh sel-sel ini setelah stres. Pelatihan yang jauh lebih berat daripada penelitian ini, telah dikaitkan dengan jaringan parut dan aritmia miokard. Penelitian ini dapat disimpulkan bahwa lari intensitas tinggi sejauh $5 \mathrm{~km}$ pada subjek yang sehat dapat menginduksi penurunan sensitivitas insulin yang tidak sepenuhnya dikompensasi untuk 
menjaga kadar glukosa plasma tetap konstan meskipun tingkat insulin serum meningkat secara substansial. Penurunan sensitivitas insulin, peningkatan serum dan kortisol saliva, serta Troponin $\mathrm{T}$ menunjukkan bahwa berlari $5 \mathrm{~km}$ dengan kecepatan maksimal mungkin tidak memiliki efek kardiovaskular yang menguntungkan ${ }^{15}$.

\section{Kesimpulan}

Patofisiologi peningkatan high sentivity cardiac troponin (hs-cTn) saat ini belum dapat dipahami dengan baik. Beberapa hipotesis telah diajukan, seperti kebocoran transmembran dari cytoplasmic free cTnT dan cTnI atau penurunan clearance troponin dari plasma, keduanya disebabkan oleh kelebihan muatan radikal bebas, peregangan miokard, peningkatan suhu inti, atau perubahan dari $\mathrm{pH}$. Terdapat hubungan terbalik antara Cardiorespiratory Fitness (CRF) dengan hs-cTnT dalam kelompok pria dan wanita yang umumnya sehat. Peningkatan cTnI setelah latihan anaerobik disebabkan oleh ketersediaan energi rendah. Penelitian lebih lanjut diperlukan dengan studi prospektif yang sepenuhnya untuk mengevaluasi patofisiologi yang mendasari peningkatkan high sentivity cardiac troponin (hs-cTn) adalah strategi yang efektif untuk mencegah atau membatasi cedera jantung subklinis kronis, serta olahraga yang aman bagi jantung.

\section{DAFTAR PUSTAKA}

1. Park, K.C., Gaze, D.C., Collinson, P.O., Marber, M.S. Cardiac Troponins: from Myocardial Infarction to Chronic Disease. Oxford University Press on behalf of the European Society of Cardiology. 2017; 113, 1708-1718.

2. Rittoo, D.,Jones, A., Lecky, B., Neithercut, D. Elevation of Cardiac Troponin T, But Not Cardiac Troponin I, in Patients With Neuromuscular Diseases. Journal of the American College of Cardiology. 2014; Vol. 63, No. 22.

3. Li, F., Yi, L., Yan, H., Wang, X., Nie, J., Zhang, H., Hoo ,F.K.F, Zang, Y., Yang, S., Lu, Y. High-Sensitivity Cardiac Troponin T Release After a Single Bout of High-Intensity Interval Exercise in Experienced Marathon Runners. Journal of Exercise Science \& Fitness. 2017; $15: 49-54$.

4. Eijsvogels, T.M.H., Veltmeijer, M.T.W., George, K., Hopman, M.T.E., Thijssen, D.H.J. The Impact of Obesity on Cardiac Troponin Levels After Prolonged Exercise in Humans. European Journal Applied Physiology. 2012; 112:1725-1732.

5. Klinkenberg, L.J.J., Luyten, P., Linden, v.d.N., Kim Urgel, K., Snijders, D.P.C., Knackstedt, C., Robert Dennert, R., Kietselaer, B.L.J.H., Alma M.A. Mingels, A.M.A., Eline P.M. Cardinaels, E.P.M., Peeters F.E.C.M., Suijlen, J.D.E.v, Kate, J.t., Marsch, E., Theelen, T.L., Sluimer, J.C., Wouters, K., Otto Bekers, O., Bekkers, S.C.A.M., Loon, L.J.C.v., Visser, M.P.v.D Meex, S.J.R. Cardiac Troponin $\mathrm{T}$ and I Release After a 30$\mathrm{km}$ Run. The American Journal of Cardiology. 2016;118:281-287. 
6. Shave, R., Baggish, A., George, K., Wood, M., Scharhag, J., Whyte, G., Gaze, D.,Thompson, P.D. ExerciseInduced Cardiac Troponin Elevation : Evidence, Mechanisms, and Implications. Journal of the American College of Cardiology. 2010; Vol. 56, No. 3.

7. Xu, R.Y., Zhu, X.F., Yang, Y., Ye, P., High-Sensitive Cardiac Troponin T. Journal of Geriatric Cardiology. 2013; 10: 102-109.

8. Garg, P., Morris, P., Fazlanie, A.L., Vijayan, S., Dancso, B., Dastidar, A.G., Plein, S., Mueller, C., Haaf, P. Cardiac Biomarkers of Acute Coronary Syndrome: from History to High-Sensitivity Cardiac Troponin. Intern Emerg Med. 2017; 12:147-155.

9. Hamedani, F. S., Katus, H.A., Meder, B. Cardiac Biomarker Changes After Endurance Sports. Journal of The American College of Cardiology. 2016. http://www.acc.org.

10. Hamedani, F.S., Kayvanpour, E, Frankenstein, L., Mereles, D., Amr, A., Buss, S., Keller, A., Evangelos Giannitsis, E., Jensen, K., Katus, H.A., Meder, B. Biomarker Changes after Strenuous Exercise Can Mimic Pulmonary Embolism and Cardiac Injury - A Metaanalysis of 45 Studies. American Association for Clinical Chemistry. 2015; 61:10 1246-1255.

11. Vilela, E.M., Bastos, J.C.C., Rodrigues, R.P., Nunes, J.P.L. HighSensitivity Troponin After Running a Systematic Review. Netherlands The Journal of Medicine. 2014; Vol 72 No 1.

12. DeFina, L. F., Willis, B.L., Radford, N.B., Christenson, R.H., deFilippi, C.R., de Lemos, J.A. Cardiorespiratory Fitness and Highly Sensitive Cardiac Troponin Levels in a
Preventive Medicine Cohort. Journal of the American Heart Association. 2016; 5:e03781.

13. Baird, M. F., Grace, F., Sculthorpe, N., Graham, S.M., Fleming, A., Baker, J.S. Evidence of Direct Cardiac Damage Following High-Intensity Exercise in Chronic Energy Restriction. Medicine. 2017; 96:27(e7030).

14. Tian,Y., Nie, J., Huang, C., George, K.P., The Kinetics of Highly Sensitive Cardiac Troponin T Release after Prolonged Treadmill Exercise in Adolescent and Adult Athletes. Journal of Applied Physiology. 2012; 113: 418-425.

15. Keselman, B., Vergara, M., Nyberg, S., Nystrom, F.H. A Randomized Cross-Over Study of The Acute Effects of Running $5 \mathrm{~km}$ on Glucose, Insulin, Metabolic Rate, Cortisol and Troponin T. PLoS ONE. 2017; 12(6): e0179401. 